\title{
Changes in $\alpha$ - and $\beta$-amylase during Storage of Sweetpotato Lines with Varying Starch Hydrolysis Potential
}

\author{
Teresa A. Morrison1, Russell Pressey, and Stanley J. Kays \\ Department of Horticulture, 1111 Miller Plant Sciences Building, The University of Georgia, Athens, \\ GA 30602 \\ Additional index words. low flavor impact, staple-type lines, polyclonal anti-B-amylase, polyacrylamide gel electrophoresis, \\ HPLC sugar analysis, Ipomoea batutas
}

\begin{abstract}
Staple-type lines of sweetpotato [Ipomoea batatus (L.) Lam.] do not sweeten significantly upon cooking as compared to the traditional-type lines. Four lines exhibiting distinct differences in sweetness after cooking were evaluated for changes in $\alpha$ - and $\beta$-amylase activity and reducing sugars (by HPLC) at harvest, after curing, and at intervals during 180 days of storage. The traditional cultivar 'Jewel' and staple-type line 'Sumor' displayed high a- and B-amylase activities, which rose from low levels at harvest to peak levels $\approx 90$ days into the storage period. Staple-type lines '99' and '86' displayed significantly lower a- and B-amylase activities. By using polyclonal sweetpotato B-amylase antibody and western blot following native- and sodium dodecyl sulfate-polyacrylamide gel electrophoresis, it was confirmed that a lower level of Bamylase synthesis existed in '99' and '86'. Quantitatively, 'Jewel', 'Sumor', and an additional staple-type line, 'HiDry', had 361,374 , and $365 \mu \mathrm{g} B$-amylase protein per gram of fresh storage root tissue, respectively, while '99' and '86' possessed <60 and $12 \mu \mathrm{g} \cdot \mathrm{g}^{-1}$, respectively. In raw roots, individual (glucose, fructose, and sucrose) and total sugar concentrations were significantly higher in 'Jewel' than in 'Sumor', '99', or '86'. Only trace amounts of maltose were found in raw roots of any line. Sucrose, glucose, and fructose concentrations decreased with baking in all lines except '86', in which they increased. There was substantial maltose produced by baking 'Jewel' and 'Sumor', but only trace amounts found in baked '99' and '86'. Sweetpotato germplasm can be separated into four general classes based on initial sugar concentration and changes during cooking: 1) low sugars/low starch hydrolysis, 2) low sugars/high starch hydrolysis, 3) high sugars/low starch hydrolysis, and 4) high sugars/high starch hydrolysis. At least two mechanisms may confer the lack of starch hydrolysis and subsequent sweetening in staple-type sweetpotato: 1) inhibition of B-amylase synthesis, and 2) a nonenzyme mediated mechanism.
\end{abstract}

The sweetpotato represents the sixth most important food crop in the world (FAO, 1986). Despite its agronomic and nutritional advantages, consumption has declined in recent decades. This decline is thought to be in part due to the dominant flavor of the cooked product (Kays, 1988). To circumvent this problem, interest has been focused on the development of nonsweet, staple-type lines with considerably lower total sugar production during baking than the traditional sweet lines. The availability of sweetpotatoes with a lower flavor impact would increase the potential flavor diversity that could be achieved in foods in which the sweetpotato is the major component, and in so doing make the sweetpotato more acceptable to populations that currently do not use or under use the crop (Kays, 1988; Tsou and Villareal, 1982).

Sweetness in the traditional cooked sweetpotato is largely due to hydrolysis of starch to maltose and short-chain branched oligosaccharides (limit dextrins) via the starch hydrolyzing enzymes, $\alpha-$ amylase [E.C. 3.2.1.1] $(\alpha-(1,4)$ glucan glucohydrolase) and Bamylase [E.C. 3.2.1.2] $(\alpha-(1,4)$ glucan maltohydrolase) (Bird and Hopkins, 1954; Deobald et al., 1968, 1969; Ikemiya and Deobald, 1966; Murata, 1970). Beta-amylase attacks the next-to-last gly-

Received for publication 24 July 1991. Accepted for publication 21 Sept. 1992. Correspondence should be directed to T.A. Morrison. Mention of trade names in this publication does not imply endorsement of products named nor criticism of similar ones not mentioned. The cost of publishing this paper was defrayed in part by the payment of page charges. Under postal regulations, this paper therefore must be hereby marked advertisement solely to indicate this fact.

'Plant Physiologist, U.S. Dept. of Agriculture, Agricultural Research Service, Field Crops Research Unit, Agronomy Dept., Iowa State University, Ames, IA 50011. ${ }^{2}$ Research Chemist, U.S. Dept. of Agriculture, Agricultural Research Service, Plant Physiology Unit, Richard B. Russell Agricultural Research Center, P.O. Box 5677, Athens, GA 30603. cosidic bond from the nonreducing end of starch, releasing maltose and low molecular weight "limit dextrins" containing a-(1,6)glucosidic branch points that neither $\alpha$ - nor $\beta$-amylases hydrolyze. The primary $B$-amylolysis product, maltose, confers to cooked roots the sweetness characteristic of the traditional sweetpotato, though maltose is substantially less sweet than sucrose, glucose, or fructose (Biester et al., 1925; Hammett and Barrentine, 1961; Losh et al., 1981; Picha, 1986; Sistrunk et al., 1954; Walter et al., 1975, 1976).

Nothing has been reported on the nature of $\alpha-$ and $\beta$-amylase in staple-type sweetpotato lines and on total sugar changes in raw and baked roots of these lines during curing and storage, though considerable information is available on these systems in traditional cultivars. The activities of $\alpha$ - and $\beta$-amylase in fresh, cured, and stored roots and alterations in individual sugars during baking of traditional and staple-type sweetpotatoes are described. Further, the mechanisms by which staple-type lines have repressed starch hydrolysis are explored using polyclonal antibody to sweetpotato ß-amylase.

\section{Materials and Methods}

Preparation of sweetpotato extracts. Four sweetpotato lines, 'Jewel', 'Sumor', '99', and '86' were randomly sampled (six roots per line) from freshly harvested roots, from roots harvested and cured 7 days at $29.5 \mathrm{C}$ and $85 \% \mathrm{RH}$, and from roots harvested, cured, and stored at $12.5 \mathrm{C}$ for $7,14,21,28,35,60,90,120,150$, and 180 days. Roots were washed, peeled, and $50 \mathrm{~g}$ composite samples within each line were homogenized with $100 \mathrm{ml}$ of 0.15 M NaCl solution in a Virtis "45" homogenizer (Virtis Co., Gardiner, N.Y.) for 2.5 minutes followed by a Polytron homogenizer 
(Brinkmann Instruments, Westbury, N.Y.) for $1 \mathrm{~min}$. The extracts were centrifuged $20 \mathrm{~min}$ at $15,000 \mathrm{rpm}$ (0C) in a Sorvall RC-5B refrigerated centrifuge (DuPont Instruments, Newtown, Conn.). The supernatant was dialyzed $24 \mathrm{~h}$ in Spectrapor membrane dialysis tubing with a molecular weight cutoff of 12,000 to 14,000 (Spectrum Medical Industries, Los Angeles) in 4 liters of $0.15 \mathrm{M}$ $\mathrm{NaCl}$ solution at $4 \mathrm{C}$.

Alpha-amylase determination. Rinderknecht et al. (1967) established that hydrolysis of dye-bound starch by $\alpha$-amylase causes a release of blue pigment into solution that is proportional over a given time interval to the amount of enzyme in the sample. This chromogenic method was adapted by Walter and Purcell (1973) for investigating $\alpha$-amylase levels in sweetpotato cultivars and was used in this study with minor modification.

Two milliliters of starch azure solution (product S-7629; Sigma Chemical Co., St. Louis) (0.5 g starch azure per $25 \mathrm{ml} 0.2 \mathrm{M}$ MES at $\mathrm{pH} 6.0), 1 \mathrm{ml} 0.15 \mathrm{M} \mathrm{NaCl}$ solution, $1 \mathrm{ml}$ distilled water, $0.1 \mathrm{ml}$ $0.05 \mathrm{M} \mathrm{CaCl}_{2}$, and $0.1 \mathrm{ml}$ dialyzed sweetpotato extract were added in sequence to $15 \mathrm{ml}$ Corex glass centrifuge tubes. The reaction solutions were agitated $30 \mathrm{~min}$ at $70 \mathrm{C}$, followed by quenching in an ice water bath to terminate hydrolysis. Reaction solutions were then centrifuged $5 \mathrm{~min}$ at high speed in a Sorval Superspeed tabletop centrifuge (Ivan Sorvall, Newtown, Conn.) to precipitate unhydrolyzed starch azure. The supernatant was read for absorbance (optical density) at $595 \mathrm{~nm}$ on a spectrophotometer (Shimadzu model UV-120-02, Columbia, Md.). Optical density readings for individual treatments (line $\times$ sampling date) were plotted over time to indicate the pattern of $\alpha$-amylase activity.

Beta-amylase determination. The colorimetric arsenomolybdate method for reducing sugars (Nelson, 1944) was used to determine $\beta$-amylase activity. In this procedure, a soluble starch solution is prepared and hydrolyzed by B-amylase, after which an aliquot of the reaction solution is boiled with (and reduced by) copper reagent. A color reagent binds copper and produces a blue solution, the intensity of which is proportional to the maltose content.

The reaction mixture contained $0.2 \mathrm{ml}$ of $0.2 \mathrm{M}$ acetate at $\mathrm{pH} 4.8$, $0.2 \mathrm{ml}$ of $0.15 \mathrm{M} \mathrm{NaCl}, 0.1 \mathrm{ml}$ of dialyzed sweetpotato extract, and $0.5 \mathrm{ml}$ of $1 \%$ soluble starch (1 g soluble starch) (Baker Chemical Co., Phillipsburg, N.J.) boiled in $100 \mathrm{ml}$ of 0.016 M sodium acetate. Blanks were duplicate sets of reaction solutions that were boiled 5 min before the $1 \%$ starch was added. The reaction solutions were incubated for $30 \mathrm{~min}$ at $37 \mathrm{C}$ with constant agitation, followed by quenching in an ice water bath. To $25 \mathrm{ml}$ Folin-Wu tubes were added $1 \mathrm{ml}$ copper reagent, $0.5 \mathrm{ml}$ distilled water, and $0.5 \mathrm{ml}$ of incubated reaction solution (Nelson, 1944). All tubes were vortexed several seconds to thoroughly mix the solution and boiled $20 \mathrm{~min}$ to denature the enzyme. After quenching in an ice water bath, $1 \mathrm{ml}$ arsenomolybdate color reagent was added and immediately vortexed. Tubes were brought up to $25 \mathrm{ml}$ volume with distilled water, mixed, and read spectrophotometrically for absorbance at $520 \mathrm{~nm}$. Absorbance values were calculated as maltose equivalents. For each treatment (line $\times$ sampling date), maltose equivalents were plotted over time to indicate the pattern of $\beta$-amylase activity.

Determination of $\beta$-amylase enzyme concentration. Five sweetpotato lines, 'Jewel', 'Sumor', 'HiDry', '99', and '86' were randomly sampled (six roots per line) from roots stored 120 days at $12.5 \mathrm{C}$ to determine $\beta$-amylase enzyme concentration in stored root tissue. The line 'Hi-Dry' is similar to 'Sumor' in enzyme and sugar behavior. Dialyzed extracts were prepared as above. Ten milliliters of dialyzed extract from each line was filtered through Sephacryl S-200 gel bed (Pharmacia Fine Chemicals, Piscataway, N.J.) with $500 \mathrm{ml} 0.15 \mathrm{M} \mathrm{NaCl}$. Fractions collected were assayed for B-amylase. Composite samples of fractions showing activity were made and concentrated to $5.0 \mathrm{ml}$ by ultrafiltration using a PM-10 membrane (Amicon Corp., Danvers, Mass.). Beta-amylase protein concentration of a dialyzed sample of commercially purified sweetpotato B-amylase (product A 7005, Sigma Chemical Co.) was determined using the Bradford assay (Bradford, 1976). The concentration of $\beta$-amylase in each sweetpotato extract was calculated from the activities relative to that for the purified $\beta$-amylase.

Production of polyclonal anti-sweetpotato $\beta$-amylase. Two 3 month-old female New Zealand white rabbits were each injected with $1 \mathrm{ml}$ of $1 \mathrm{mg} \cdot \mathrm{ml}^{-1}$ Sephacryl S-200 ultra-filtered B-amylase (Sigma Co., product A 7005) mixed with dimethyldiocta-decylammonium bromide adjuvant (DDA) (Sigma product D 2779). Two milligrams B-amylase per milliliter was prepared $1: 1(\mathrm{v} / \mathrm{v})$ with $54 \mu \mathrm{M}$ of DDA for a final injectable concentration of $1 \mathrm{mg} \cdot \mathrm{ml}^{-1} \beta$-amylase and $27 \mu \mathrm{M}$ DDA. Booster injections of $1 \mathrm{mg} \cdot \mathrm{ml}^{-1} \beta$-amylase in DDA were made every 2 weeks for 3 months. A $20 \mathrm{ml}$ normal serum blood sample was collected on the first day of the study, and $20 \mathrm{ml}$ anti-serum blood samples were taken every 2 weeks thereafter.

Immediately after normal and anti-serum blood collection, samples were placed in a water bath at $37.5 \mathrm{C}$ for $1 \mathrm{~h}$. After incubation at 4C overnight, samples were centrifuged at $2000 \mathrm{rpm}$ for $10 \mathrm{~min}$. The straw-colored serum was pipetted from the blood clot into $15 \mathrm{ml}$ Corex glass centrifuge tubes and centrifuged at $4500 \mathrm{rpm}$ for $15 \mathrm{~min}$. To the clear supernatant was added $0.02 \%$ sodium azide to control microbial growth. The protein in the supernatant precipitated by adding granular ammonium sulfate to $65 \%$ saturation, the pellet resuspended in $0.15 \mathrm{M} \mathrm{NaCl}$ and dialyzed $24 \mathrm{~h}$ with three changes of water. For storage, the dialyzed antiserum was frozen at $-20 \mathrm{C}$ in microcentrifuge tubes. Tests indicating positive antigen-antibody response were achieved using agar gel micro ouchterlony radial double diffusion (AGD) as reported by Parulekar (1984) and enzyme linked immunoabsorbent assay (ELISA). Assays were devised to establish that the anti-sweetpotato B-amylase inhibited normal $B$-amylase activity in sweetpotato root extracts.

Gel electrophoresis on undenatured and denatured $\beta$-amylase. The procedure for electrophoretic separation of proteins and western blot described by Smith ( 1987) was followed in performing both gel electrophoresis and electro-transfer (western blot) of undenatured and denatured protein. A Bio-Rad (Richmond, Calif.) mini PROTEAN II dual slab cell and mini-transblot electrophoretic transfer cell were used to run gel electrophoresis of sweetpotato $B$ amylase protein and electro-transfer of undenatured and denatured sweetpotato $\beta$-amylase protein to the nitrocellulose membrane. The electrical current setting for the electrophoretic gel and western blot was $100 \mathrm{~V}$ at $240 \mathrm{amp}$. Goat anti-rabbit IgG alkaline phosphatase (Sigma product A-8025) was used as a secondary antibody to detect complexation of the primary anti- $\beta$-amylase with $\beta$-amylase protein band. The precipitate substrate for the alkaline phosphatase used was 5-bromo-4-chloro-3-indolyl phosphate (BCIP) (p-toluidine salt) (Sigma product B-8503) and nitro blue tetrazolium (NBT) (Sigma N-6876). Thirty microliters of $100 \mu \mathrm{g} \cdot \mathrm{ml}^{-1}$ Sigma sweetpotato $\beta$-amylase, $63 \mu \mathrm{g} \cdot \mathrm{ml}^{-1}$ barley $\beta$-amylase (as antibody specificity control), and $30 \mu \mathrm{l}$ of 'Jewel', 'Sumor', 'HiDry', '99', and '86' extracts were loaded on undenaturing gel. For SDSPAGE $30 \mu \mathrm{l}$ of sephacryl S-200 ultra-filtered 'Jewel', 'Sumor', and 'HiDry', '99' and '86' extracts were loaded.

HPLC sugar determination. On each of the 12 sampling dates, $100 \mathrm{~g}$ of composited roots from each line were freeze-dried and ground to <40 mesh using a Wiley mill (Philadelphia). Similar samples were prepared from roots baked $70 \mathrm{~min}$ at $205 \mathrm{C}$ and 


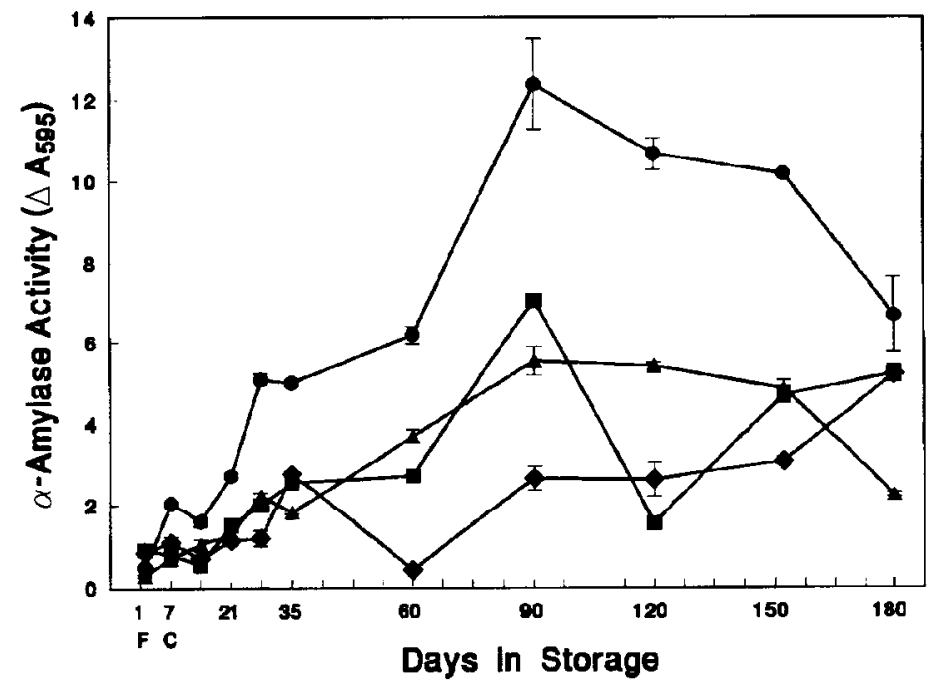

Fig. 1. Activity of $\alpha$-amylase assayed for $30 \mathrm{~min}$ in four sweetpotato lines at fresh harvest $(\mathrm{F})$, after 7 days of curing $(\mathrm{C})$, and at intervals during 180 days of storage at $12.5 \mathrm{C}$ and $85 \%$ RH. 'Sumor',

;; 'Jewel' $\mathbf{A}$; '99', 무; ' 86 ',

cooled to room temperature. All samples were stored under dessication before HPLC sugar determination.

Five grams of raw and baked freeze-dried, ground root tissue were boiled for $15 \mathrm{~min}$ in $50 \mathrm{ml} 80 \%$ ethanol, quenched in an icewater bath, washed with $80 \%$ ethanol through Whatman no. 1 filter paper, and the filtrate brought up to $100 \mathrm{ml}$. The extract was centrifuged for $15 \mathrm{~min}$ at $15,000 \mathrm{rpm}(0 \mathrm{C})$ and the supernatant stored in screw-cap vials at $-10 \mathrm{C}$. One milliliter aliquots were injected through a sample loop delivering $20 \mu$ into a Supelco carbohydrate liquid chromatography column (Supelcosil LC-NH using $75 \%$ acetonitrile: $25 \%$ water as mobile phase). An Altech model 110A pump produced a flow rate of $2 \mathrm{ml} \cdot \mathrm{min}^{-1}$. Operating temperature was $25 \mathrm{C}$. A Waters 410 differential refractometer (Waters Associates, Milford, Mass.) and LDC/Milton Roy Integrator calculated the peak area for individual sugars. The percentage of the sugars (sucrose, glucose, fructose, and maltose) in each sample was calculated using peak areas against a $1 \%$ sucrose, glucose, fructose, and maltose standard solution. The data for each individual sugar and the total sugars was analyzed separately by Duncan's multiple range test.

\section{Results}

Alpha amylase activity. Following fresh (F) harvest and curing (C), and during storage, $\alpha$-amylase activity was consistently higher in 'Sumor' than in 'Jewel', '99', or '86' (Fig. 1). 'Jewel' aamylase activity during storage was higher than ' 86 '. In '99', $\alpha-$ amylase activity varied during the storage period. Alpha-amylase activity rose in roots of all lines after harvest and reached a maximum (with the exception of ' 86 ') after $\approx 90$ days of storage.

Beta-amylase activity. The B-amylase activity of 'Jewel' and 'Sumor' was substantially higher than that of '99' or '86' (Fig. 2). 'Jewel' and 'Sumor' / $\$$-amylase activities during storage were not significantly different from each other and followed a cubic pattern (for 'Jewel' $\mathrm{y}=-8.55+5.37 \mathrm{x}-2.26 \mathrm{x}^{2}+0.03 \mathrm{x}^{3}, R^{2}=0.936$ at $P=$ 0.05 ; for 'Sumor' $\mathrm{y}=-9.35+6.23 \mathrm{x}-3.09 \mathrm{x}^{2}+0.05 \mathrm{x}^{3}, R^{2}=0.948$ at $P=0.05)$. Beta-amylase activity for these two lines rose during storage, peaking at $\approx 90$ days, after which activity decreased until the last sampling date (180 days). Regression lines for '99' and '86' displayed zero slope, each showing extremely low levels of $\beta$ amylase activity during storage (Fig. 2). This low B-amylase ac- tivity indicates that one of the following processes is present: the synthesis of the enzyme is blocked, a defective form of the enzyme with little activity is produced, or some other mechanism of inhibition is operative in these lines.

Concentration of $\beta$-amylase protein in sweetpotato extracts. Roots of 'Jewel', 'Sumor', and 'HiDry' had similarly high concentrations of $\beta$-amylase protein. On a per gram of fresh root tissue basis, 'Jewel', 'Sumor', and 'HiDry' had $\approx 365 \mu \mathrm{g}$ of $B$-amylase protein, while ' 99 ' had $\approx 17 \%$ as much and ' 86 ' had only $\approx 3 \%$ as much (Table 1).

PAGE, SDS-PAGE, and western blot of $\beta$-amylase. Polyacrylamide gel electrophoresis of Sigma sweetpotato $\beta$-amylase and sweetpotato extracts (Fig. 3) displayed $\beta$-amylase protein bands at $206 \mathrm{kd}$ for all sweetpotato B-amylases except '99' and '86', indicating that concentrations of the undenatured protein in these two lines was lower than what could be detected by coomassie brilliant blue staining. Western blot of similar samples (Fig. 4), including Sigma sweetpotato $\beta$-amylase and barley $\beta$-amylase, showed no evidence of antibody complexation by ' 99 ' and ' 86 ' $\beta$ amylase, while all other $\beta$-amylase sources did complex. Barley $\beta$ amylase protein tertiary structure appears to be sufficiently similar to sweetpotato $B$-amylase protein to be antigenic. SDS-PAGE of the $48 \mathrm{kd}$ identical subunits of $B$-amylase displayed protein bands for all lines, although bands for '99' and '86' were very faint (Fig. 5). Western blot of duplicate samples indicated that the subunit protein bands of $\beta$-amylase from 'Jewel', 'Sumor', and 'HiDry' were also antigenic (data not shown), although for ' 99 ' and ' 86 ' there was no evidence of antigen-antibody interaction. Either '99' and ' 86 ' $B$-amylase subunit protein concentrations were too low for positive immune detection or the subunits were nonantigenic.

Sugar concentration. Changes in individual and total sugar concentrations over the storage period were relatively minor. Individual (glucose, fructose, and sucrose) and total sugar concentrations were significantly higher in uncooked 'Jewel' than in the other lines (Table 2). Only trace amounts of maltose were found in any uncooked sweetpotatoes. Sugar content in raw 'Sumor', '99', and ' 86 ' were similar, although glucose and fructose levels in ' 86 ' were significantly lower than in 'Sumor' and '99'. The maltose concentrations in baked 'Jewel' and 'Sumor' had increased dramatically (Table 2), but only slightly in '99' and '86'. Lines

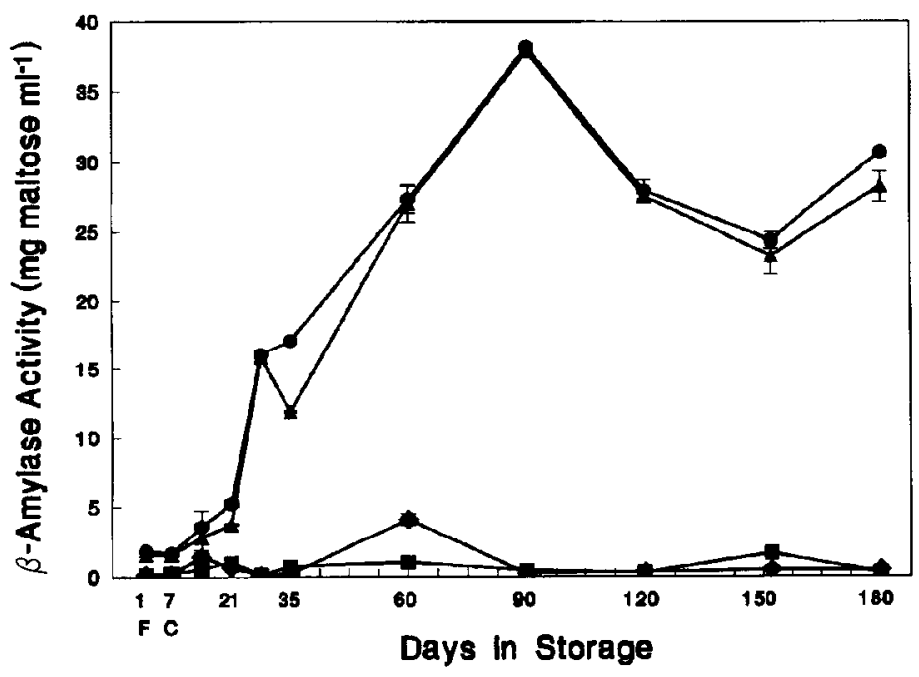

Fig. 2. Activity of B-amylase assayed for $30 \mathrm{~min}$ in four sweetpotato lines at fresh harvest(F), after 7 days of curing (C), and at intervals during 180 days of storage at $12.5 \mathrm{C}$ and $85 \%$ RH. 'Sumor', ; 'Jewel', $\mathbf{A}$; '99', $\mathbf{\square}$; ' 86 ', 
Table 1. Concentrations of $\beta$-amylase protein from traditional and stapletype sweetpotato lines.

\begin{tabular}{lcc}
\hline & \multicolumn{2}{c}{ Enzyme concn } \\
\cline { 2 - 3 } & $\mu g \cdot \mathrm{ml}^{-1}$ & $\begin{array}{c}\mu \mathrm{g} \cdot \mathrm{g}^{-1} \mathrm{fresh} w \mathrm{wt} \\
\text { of root tissue }\end{array}$ \\
Sweetpotato line & $120 \mathrm{a}^{\mathrm{z}}$ & $361 \mathrm{a}$ \\
\hline $\begin{array}{l}\text { Traditional line } \\
\text { 'Jewel' }\end{array}$ & & \\
& & $374 \mathrm{a}$ \\
Staple-type lines & $125 \mathrm{a}$ & $365 \mathrm{a}$ \\
'Sumor' & $122 \mathrm{a}$ & $59.0 \mathrm{~b}$ \\
'HiDry' & $19.7 \mathrm{~b}$ & $11.2 \mathrm{c}$ \\
'99' & $3.7 \mathrm{c}$ &
\end{tabular}

${ }^{2}$ Mean separation within columns at $P=0.05$ by Duncan's multiple range test.

'99' and ' 86 ' had only $0.62 \%$ and $0.30 \%$ of the maltose concentration of 'Sumor', respectively. The significant increase in total sugars in baked 'Jewel' and 'Sumor' was due to higher maltose levels.

\section{Discussion}

Thermal activation of $\beta$-amylase during baking (as confirmed by Balls et al., 1948; Hoover and Harmon, 1967) brought about the enzymatic hydrolysis of starch to maltose accompanied by a marginal decrease in levels of sucrose, glucose, and fructose (Table 2). Alpha-amylase activity did not appear to influence total sugar concentration. In general, activity rose following harvest, though fluctuations in activity occurred during storage. Fluctuations in $\alpha$-amylase activity during the presprouting storage period have been noted before (Collins, 1982), but there seems to be no apparent relationship between the amylase activity and total sugar content.

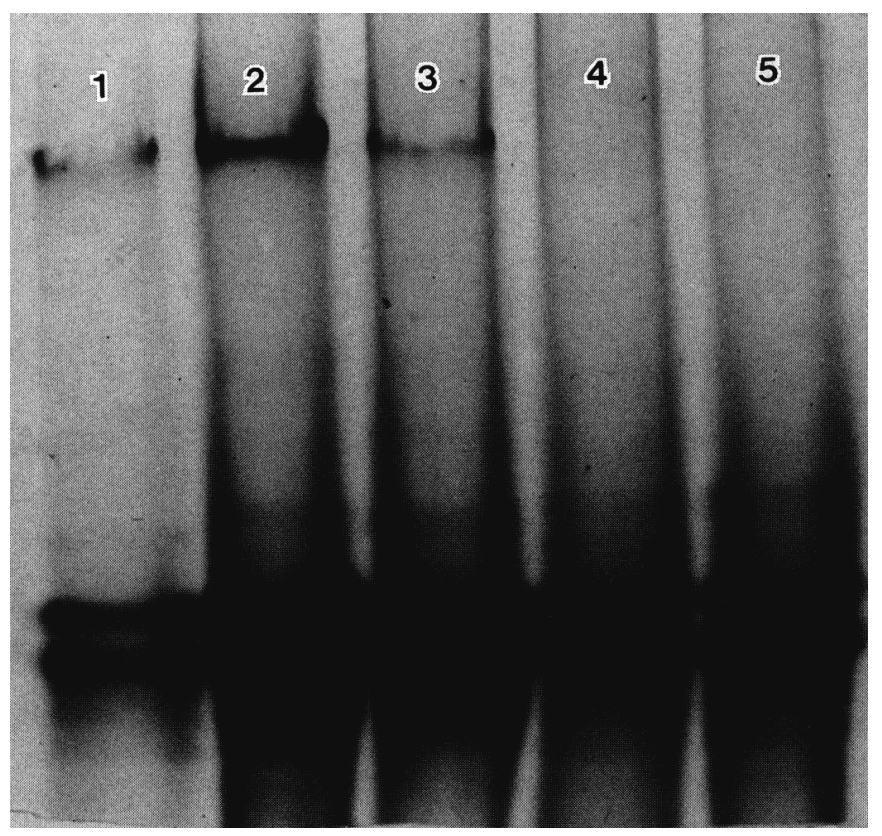

Fig. 3. Polyacrylamide gel electrophoresis of undenatured sweetpotato $ß$-amylase proteins bands from extracts of various lines are as follows: 1, 'Jewel'; 2 , 'Sumor'; 3, 'HiDry'; 4, '99'; 5, '86'.
Though there was dramatic change in total sugar concentration (primarily maltose) during baking in 'Jewel' and 'Sumor', there was little change in total sugar concentrations in baked '99' and ' 86 ' roots, as compared to uncooked roots. Concentrations of maltose did not rise appreciably in these lines during baking due to lack of $\beta$-amylase activity.

Results presented here indicate that there are two phenomena accounting for lack of sweetness in the staple-type sweetpotatoes: 1) low background levels of sucrose, glucose, fructose, and maltose; and/or 2) low levels of B-amylase mediated starch hydrolysis and maltose formation. Both factors appear to be operative in '99' and '86', i.e., low base sugar concentration and low starch hydrolysis during cooking. In 'Sumor', only low background concentrations of sugar appear to account for lack of sweetness. Significant starch hydrolysis due to high $\beta$-amylase activity, coupled with low base levels of sugars, produce a relatively nonsweet product.

While inhibition of $ß$-amylase synthesis has been suggested as the cause for low $\beta$-amylase activity, this cannot be ascertained using enzyme assays alone. To determine whether $\beta$-amylase protein was not synthesized or was produced in a nonfunctional form, polyclonal antibodies to sweetpotato $B$-amylase were raised and used to distinguish between the two possibilities. Our results indicate that in the staple-type lines ' 99 ' and ' 86 ', B-amylase protein is present in only minute quantities. The arsenomolybdate assay indicated a low level of $\beta$-amylase activity in ' 99 ' and ' 86 ', and this enzyme in these lines was barely detectable by gel electrophoresis and western blot. Whether inhibition of active Bamylase is at the transcriptional, translational, or post-translational level has yet to be resolved. Likewise, it is not yet clear if the stapletype lines represent identical, similar, or distinctly different forms of the enzyme.

Based on this and previous work, sweetpotatoes may be separated into four general classes according to raw root sugar concentration and starch hydrolytic activity during baking. The classifications include: 1) low initial sugar concentration/low starch hydrolysis, 2) low initial sugar concentration/high starch hydrolysis, 3) high initial sugar concentration/low starch hydrolysis, and 4) high initial sugar concentration/high starch hydrolysis. The initial sucrose, glucose, and fructose concentrations in raw sweetpotato represent the first classification criteria. Class 1 lines have low inherent sugar contents (i.e., 8.0\% and 6.0\% total sugar for '99' and ' 86 ', respectively) and produce very little maltose upon cooking. In '99' and ' 86 ', the resulting baked product is bland and has a substantially reduced flavor impact due to the lack of sweetness. Both '99' and ' 86 ' were judged by a panel of taste-testers to be very low in sweetness and had several of the organoleptic and aromatic characteristics commonly found in traditional baked sweetpotatoes. Lack of starch hydrolysis in '99' and ' 86 ' is probably due to insufficient $\beta$-amylase but could be caused in other lines by other mechanisms, e.g. inhibitors, starch-based structural resistance to hydrolysis. An absence of sweetness per se may not be synonymous with low flavor, since a substantial cross-section of compounds other than sugars modulate flavor Kays, 1988).

Class 2 lines have low initial sugar concentrations and high starch hydrolysis activity leading to abundant maltose production upon starch hydrolysis. The resulting baked product has been rated slightly sweet by taste panels. 'Sumor' and 'HiDry' are examples of such lines. During cooking, starch hydrolysis by $\alpha-$ and $\beta-$ amylase produces abundant maltose, as evidenced by the $26.3 \%$ total sugar content in the 'Sumor' baked product. Sucrose, glucose, and fructose do not contribute to this rise in total sugars. Although amylase activity is high and maltose concentrations are similar to those found in baked 'Jewel', the 'Sumor' baked product has little 


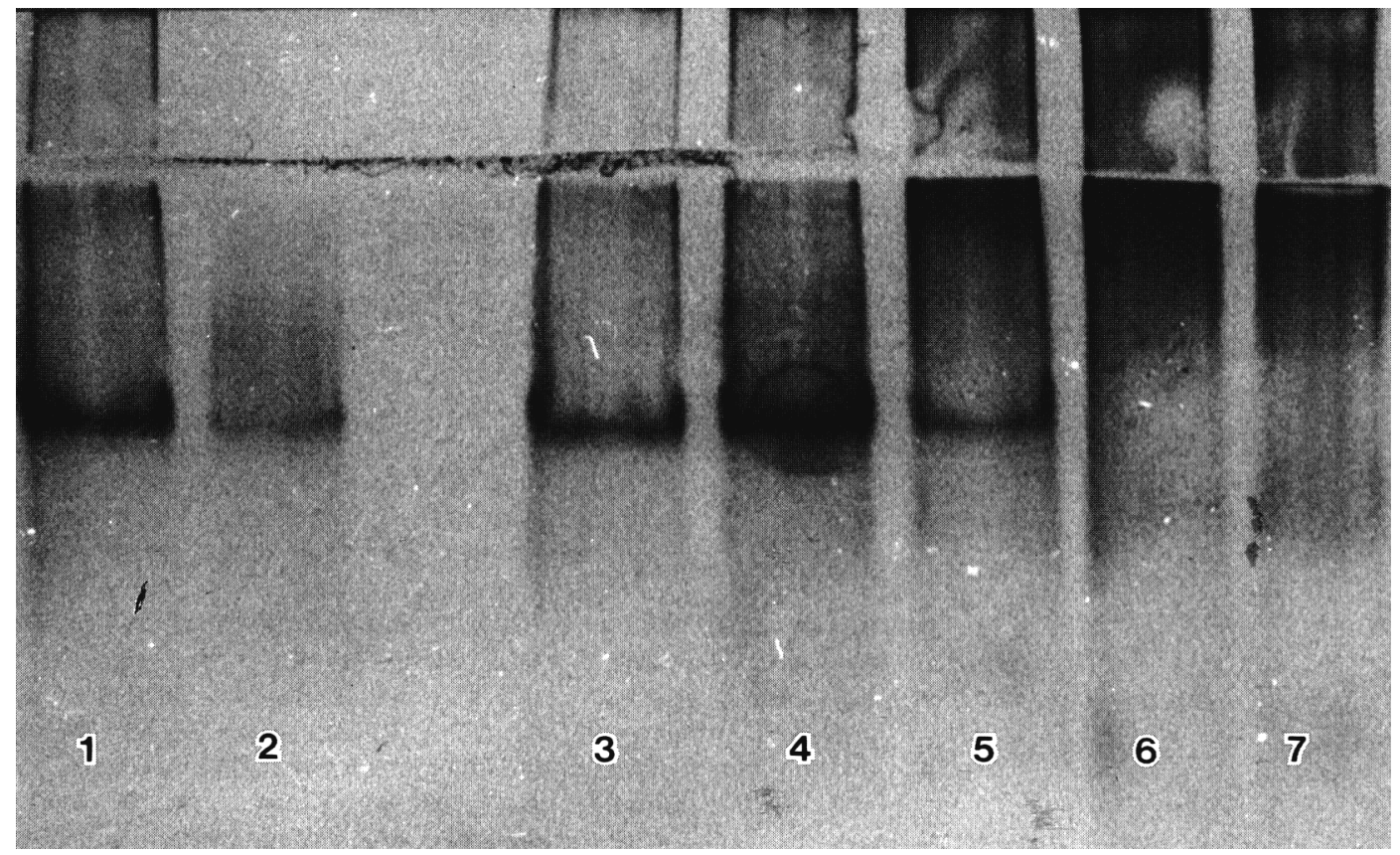

Fig. 4. Western blot of undenatured sweetpotato and barley $\beta$-amylase proteins following PAGE. 1, Sigma sweetpotato ß-amylase protein; 2, Sigma barley ß-amylase protein. Sweetpotato ß-amylase proteins are as follows: 3, 'Jewel'; 4, 'Sumor'; 5, 'HiDry'; 6, '99'; 7, '86'.

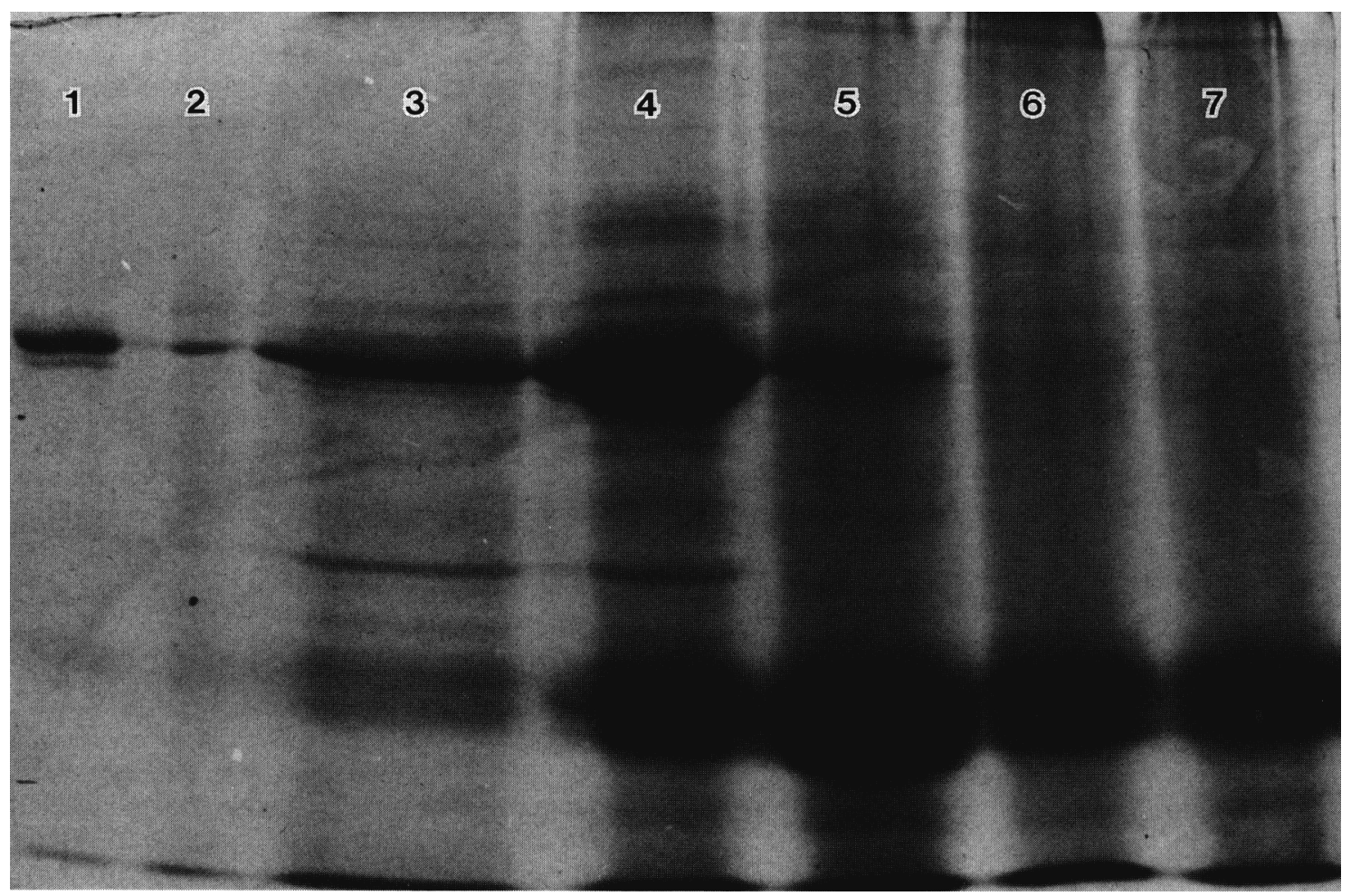

Fig. 5. Sodium dodecyl sulfate-polyacrylamide gel electrophoresis of denatured sweetpotato and barley $\beta$-amylase proteins (48 KD). 1 , Sigma sweetpotato B-amylase protein, 2, Sigma barley B-amylase protein. Sweetpotato B-amylase proteins are as follows: 3, 'Jewel'; 4, 'Sumor'; 5, 'HiDry'; 6, '99'; 7, '86’. 
Table 2. Concentrations of maltose, sucrose, glucose, fructose, and total sugars in raw and baked sweetpotato lines.

\begin{tabular}{|c|c|c|c|}
\hline \multirow[b]{2}{*}{ Sugar } & \multirow{2}{*}{$\begin{array}{c}\text { Sweetpotato } \\
\text { line }\end{array}$} & \multicolumn{2}{|c|}{$\begin{array}{c}\text { Sugar concn } \\
\text { in sweetpotatoes }(\%)\end{array}$} \\
\hline & & Raw & Baked \\
\hline \multirow[t]{4}{*}{$\overline{\text { Maltose }}$} & 'Jewel' & $0.05 b^{2}$ & $18.5 \mathrm{a}$ \\
\hline & 'Sumor' & $0.16 \mathrm{~b}$ & $17.7 \mathrm{a}$ \\
\hline & ‘99' & $0.07 \mathrm{~b}$ & $0.11 \mathrm{~b}$ \\
\hline & ' 86 ' & $0.01 \mathrm{~b}$ & $0.05 \mathrm{~b}$ \\
\hline \multirow[t]{4}{*}{ Sucrose } & 'Jewel' & $12.5 \mathrm{a}$ & 7.76 bc \\
\hline & 'Sumor' & $6.22 \mathrm{~cd}$ & $5.61 \mathrm{~d}$ \\
\hline & ‘99’ & $6.27 \mathrm{~cd}$ & $5.60 \mathrm{~d}$ \\
\hline & ' 86 ' & $5.62 \mathrm{~d}$ & $9.06 \mathrm{~b}$ \\
\hline \multirow[t]{4}{*}{ Glucose } & 'Jewel' & $4.54 \mathrm{a}$ & $2.57 \mathrm{~b}$ \\
\hline & 'Sumor' & $0.99 \mathrm{c}$ & $0.91 \mathrm{~cd}$ \\
\hline & ‘99' & $0.91 \mathrm{~cd}$ & $0.55 \mathrm{cde}$ \\
\hline & $' 86$ ' & $0.25 \mathrm{e}$ & $0.37 \mathrm{de}$ \\
\hline \multirow[t]{4}{*}{ Fructose } & 'Jewel' & $3.43 \mathrm{a}$ & $2.25 \mathrm{~b}$ \\
\hline & 'Sumor' & $0.73 b c$ & $0.76 b c$ \\
\hline & '99' & $0.73 \mathrm{bc}$ & $0.58 \mathrm{bc}$ \\
\hline & ' 86 ' & $0.13 \mathrm{~d}$ & $0.41 \mathrm{~cd}$ \\
\hline \multirow[t]{4}{*}{ Total sugars } & 'Jewel' & $20.6 \mathrm{c}$ & $31.0 \mathrm{a}$ \\
\hline & 'Sumor' & $8.09 \mathrm{de}$ & $26.3 \mathrm{~b}$ \\
\hline & '99' & $7.99 \mathrm{de}$ & $6.85 \mathrm{e}$ \\
\hline & ' 86 ' & $6.01 \mathrm{e}$ & $10.7 \mathrm{~d}$ \\
\hline
\end{tabular}
test.

of the sweetness characteristic of the traditional cultivars due to the substantially lower sweetness of maltose as compared to sucrose, fructose, or glucose (Biester, 1925). For example, if the relative level of sweetness of sucrose is 1.0 , then glucose $=0.74$, fructose $=1.73$, and maltose $=0.33$. Hence, three molecules of maltose are needed to equal the sweetness of one molecule of sucrose.

The third class is comprised of lines that have high initial sugar concentrations but low starch hydrolysis and maltose formation. The sweetness of the product, therefore, is a function of the level of sugar present in the uncooked roots. None of the lines evaluated belong to this class.

Traditional USA sweetpotato cultivars make up Class 4. These lines have relatively high initial concentrations of sucrose, glucose, and fructose, and high levels of starch hydrolysis and maltose formation upon baking. The baked product is typically quite sweet. 'Jewel', an orange-flesh, traditional cultivar has significantly higher glucose, fructose, and sucrose concentrations and displays a higher initial total sugar concentration $(20.6 \%)$ in raw roots than the other lines. Maltose production by $B$-amylase activity elevates total sugar concentrations to $31.0 \%$ in the baked product.

At present, virtually the only commercially successful processed products made from sweetpotatoes are canned roots, baby food, and patties (Kays, 1985). This is in contrast to the white potato (Solanum tuberosum, L.), from which a broad range of processed products are derived. Use of nonsweet, low-flavor sweetpotatoes in breeding programs should allow a much broader range of sweetpotato flavors to be developed which, in turn, will allow targeting new uses and markets for the crop.

\section{Literature Cited}

Balls, A.K., M.K. Walden, and R.R. Thompson. 1948. A crystalline Bamylase from sweet potatoes. J. Biol. Chem. 173:9-19.

Biester, A., M.W. Wood, and C.S. Wahlin. 1925. Carbohydrate studies. I. The relative sweetness of pure sugars. Amer. J. Physiol. 73:387-396. Bird, R. and R.H. Hopkins. 1954. The mechanism of B-amylase action: 2. Multichain action on amylose fission products. Biochem. J. 56:140146.

Bradford, M.M. 1976. A rapid and sensitive method for the quantitation of microgram quantities of protein utilizing the principle of protein-dye binding. Anal. Biochem. 72:248-254.

Collins, W.W. 1982. Alpha-amylase activity in sweet potatoes. HortScience 17:156. (Abstr.)

Deobald, H.J., V.C. Hasling, E.A. Catalano, and T.A. McLemore. 1969. Relationship of sugar formation and sweet potato alpha-amylase activity during processing for flake production. Food Technol. 23(6):118-121.

Deobald, H.J., T.A. McLemore, V.C. Hasling, and E.A. Catalano. 1968. Control of sweet potato alpha-amylase for producing optimum quality precooked dehydrated flakes. Food Technol. 22(5):93-96.

FAO. 1986. Agricultural Production Yearbook. U.N. Food and Agr. Organization. Rome. vol. 40.

Hammett, H.L. and B.F. Barrentine. 1961. Some effects of variety, curing, and baking upon the carbohydrate content of sweetpotatoes. J. Amer. Soc. Hort. Sci. 78:421-426.

Hoover, M.W. and S.J. Harmon. 1967. Carbohydrate changes in sweet potato flakes made by the enzyme activation technique. Food Technol. 21:115-118.

Ikemiya, M. and H.J. Deobald. 1966. New characteristic alpha-amylase in sweet potatoes. J. Agr. and Food Chem. 14:237-341.

Kays, S.J. 1985. Formulated sweet potato products, p. 205-218. In: Sweet 
potato products: A natural resource of the tropics. J. Bouwkamp (ed.), CRC Press, Boca Raton, Fla.

Kays, S.J. 1988. Strategies for selecting conventional and new flavor types of tropical root and tuber crops to increase consumer acceptance and use, p. 178-188. Proc. 8th Intl. Symp. Trop. Root Crops, Bangkok, Thailand.

Losh, J.M., J.A. Phillips, J.M. Axelson, and R.S. Schulman. 1981. Sweet potato quality after baking. J. Food Sci. 46:283-286, 290.

Murata, N. 1970. Enzymatic mechanism of starch synthesis in sweet potato roots: part III. the composition of carbohydrates and soluble nucleotides in the developing sweet potato roots. J. Agr. Chem. Soc. (Jpn) 44:412-421.

Nelson, N. 1944. A photometric adaptation of the Somogyi method for the determination of glucose. J. Biol. Chem. 153:375-380.

Parulekar. S.D. 1984. Agar gel micro Ouchterlony radial double diffusion (AGD), p. 32-65. In: S.S. Kelkar, P.M. Khare, and H.I. Jhala (eds.). Gel immuno-diffusion techniques in research and laboratory medicine. Sangam Books, London.

Picha, D.H. 1986. Carbohydrate changes in sweet potatoes during curing and storage. J. Amer. Soc. Hort. Sci. 112:89-92.

Rinderknecht, H., P. Wilding, and B.J. Haverback. 1967. A new method for the determination of $\alpha$-amylase. Experientia 22:805.

Sistrunk, W.A., J.C. Miller, and L.G. Jones. 1954. Carbohydrate changes during storage and cooking of sweet potatoes. Food Technol. 8:223226.

Smith, J.A. 1987. Electrophoretic separation of proteins, p. 10.0.110.16.10. In: F.M. Ausubel, R. Brent, R.E. Kingston, D.D. Moore, J.G. Seidman, J.A. Smith, and K. Struhl (eds.). Current protocols in molecular biology. Wiley, New York.

Tsou, S.C.S and R.L. Villareal. 1982. Resistance to eating sweet potato, p. 45-58. In: R.L. Villareal and T.D. Griggs (eds.). Sweet Potato: Proc. 1st Intl. Symp. Asian Veg. Res. Dev. Center, Shanhua, Tainan, Taiwan, China.

Walter, W.M. and A.E. Purcell. 1973. Alpha-amylase in sweet potatoes: A comparison between the amyloclastic and chromogenic starch methods of analysis. J. Food Sci. 42: 1374-1 377.

Walter, W.M, A.E. Purcell, and M.W. Hoover. 1976. Changes in amyloid carbohydrates during preparation of sweet potato flakes. J. Food Sci. 42:1374-1377.

Walter, W.M., A.E. Purcell, and A.M. Nelson. 1975. Effects of amylolytic enzymes on "moistness" and carbohydrate changes of baked sweet potato cultivars. J. Food Sci. 40:793-796. 